\title{
Effect of sodium 2-methyl-4-chlorophenoxyacetate on spermatogenesis in the rat
}

\author{
H. Elo and M. Parvinen* \\ Institute of Biomedical Sciences, University of Tampere, Tampere, and \\ *Department of Anatomy, University of Turku, Turku, Finland
}

The substance 2-methyl-4-chlorophenoxyacetic acid (MCPA) is a widely used herbicide. Chlorophenoxyacetic acids or their derivatives and some impurities have teratogenic and embryotoxic properties in several animals (Courtney \& Moore, 1971; Yasuda \& Maeda, 1972), but little is known about the effects of MCPA or other chlorophenoxyacetic acids on the structure and function of male reproductive organs. In a short-term feeding study MCPA increased the relative weight of rat testes, but did not induce obvious histological alterations in the testes or other organs (Verschuuren, Kroes $\&$ den Tonkelaar, 1975). Because 2,4-dichlorophenoxyacetic acid and MCPA cause reduced fertility in rats (Schiller, 1964), we studied the effects of short-term administration of the sodium salt of MCPA on the composition of the seminiferous epithelium and spermatogenesis in the rat.

The sodium salt (MCPA-Na) was prepared by neutralizing pure MCPA (99.6\% MCPA, obtained from Kemisk Vaerk Køge A/S, Denmark) with sodium hydroxide. Sprague-Dawley rats, aged 9 weeks and weighing $217 \pm 35 \mathrm{~g}$, were allowed free access to drinking water containing 100-3000 p.p.m. MCPA-Na for 2 months, before being killed. The rats were housed 3-5/cage and the dose of MCPA-Na received was calculated from the amount of water imbibed each day. At autopsy, the animals and their testes were weighed and the testes were fixed in Bouin's fluid. The $5 \mu \mathrm{m}$-thick paraffin-wax sections were stained with PAS-haematoxylin or haematoxylin-eosin.

Two sections of each testis were examined and in each section 50 seminiferous tubules were evaluated at random. Alterations in the seminiferous epithelium, e.g. marked decrease in the amount of certain cell types, disorder in the epithelium, cells with a pyknotic nucleus, were scored using a scale from 0 to 10 according to the following criteria: (10) normal spermatogenesis in all tubules; (9) some tubules degenerated; about 5\% (8), 5-50\%(7) and 50-95\%(6) of tubules showed degenerative alterations; (5) more than $95 \%$ of tubules degenerated although most tubules contained round spermatids; (4) epithelium degenerated in all tubules, round spermatids occurred in about $40 \%$ of tubules and elongating spermatids in a few tubules; (3) no spermatids in the tubules but $>50 \%$ of tubules contained primary spermatocytes; (2) $<20 \%$ of tubules contained primary spermatocytes while in the other tubules there were only spermatogonia and Sertoli cells; complete dedifferentiation of some tubules had occurred; (1) only spermatogonia and Sertoli cells were in the tubules; (0) dedifferentiated cells and hyalinization were present in all tubules.

Table 1. Effects of the short-term administration of MCPA-Na on the body weight and testes of the rat (mean \pm S.D.)

\begin{tabular}{cccccc}
\hline $\begin{array}{c}\text { p.p.m. MCPA-Na } \\
\text { in drinking water } \\
\text { (average dose in } \\
\mathrm{mg} / \mathrm{kg} / \text { day) }\end{array}$ & $\begin{array}{c}\text { No. } \\
\text { of } \\
\text { rats }\end{array}$ & $\begin{array}{c}\text { Body wt at } \\
\text { end of } \\
\text { treatment }(\mathrm{g})\end{array}$ & $\begin{array}{c}\text { \% Increase of } \\
\text { body wt } \\
\text { during treatment }\end{array}$ & $\begin{array}{c}\text { Wt of testes as } \\
\% \text { of body wt }\end{array}$ & $\begin{array}{c}\text { Histological alteration in the } \\
\text { seminiferous epithelium }\end{array}$ \\
\hline 0 & 6 & $385 \pm 17$ & $76 \cdot 1 \pm 23 \cdot 7$ & $0 \cdot 88 \pm 0 \cdot 04$ & $10,10,10,9,10,9.10(9 \cdot 7)$ \\
$100(13)$ & 5 & $358 \pm 24$ & $72 \cdot 5 \pm 16 \cdot 2$ & $0 \cdot 93 \pm 0 \cdot 07$ & $8,9,8,9,10,10(9 \cdot 0)$ \\
$500(61)$ & 6 & $365 \pm 46$ & $81 \cdot 6 \pm 54 \cdot 9$ & $0 \cdot 92 \pm 0 \cdot 22$ & $9,10,4 \ddagger, 8,10 \ddagger, 9,9,(8 \cdot 4)$ \\
$1000(112)$ & 9 & $324 \pm 29$ & $51 \cdot 2 \pm 17 \cdot 6^{*}$ & $0 \cdot 98 \pm 0 \cdot 12$ & $10,10,9 \ddagger, 5,8.7,8,8 \ddagger, 9,9(8 \cdot 3)$ \\
$2000(190)$ & 9 & $284 \pm 35$ & $27 \cdot 5 \pm 14 \cdot 5^{* * *}$ & $0 \cdot 91 \pm 0 \cdot 18$ & $9,7,2,8 \ddagger, 5,6,6,9 \ddagger, 8(6 \cdot 7)$ \\
$3000(246)$ & 5 & $301 \pm 31$ & $18 \cdot 4 \pm 14 \cdot 5^{* * *}$ & $0 \cdot 83 \pm 0 \cdot 26$ & $7,8,5,6,4,9,8(6 \cdot 7)$ \\
\hline
\end{tabular}

Increase of body weight and relative weight of testes were tested by Student's $t$ test: ${ }^{*} P<0.05, * * * P<0.001$.

Each figure represents the testes of one rat; average alteration in parentheses.

$\ddagger$ Animal showed symptoms of pneumonia. 
As seen in Table 1, a concentration of 1000 p.p.m. MCPA-Na or more in the drinking water retarded the increase in body weight but there were no statistically significant differences in the relative weights of the testes. Concentrations above 1000 p.p.m. also induced degenerative alterations in the seminiferous epithelium. The first alteration was the loss of maturation stages 15-19 (spermatids) (Leblond \& Clermont, 1952) in some tubules. Concentrations above 2000 p.p.m. caused an enhanced loss of maturing spermatids, and in occasional cases degeneration of young spermatids and pachytene spermatocytes. Giant cells (Zysk, Bushway, Whistler \& Carlton, 1975) formed by young round nucleated spermatids were seen in some damaged tubules. At the concentration of 3000 p.p.m., however, some animals with almost normal spermatogenesis were found.

Our results indicate that relatively high concentrations of MCPA-Na in the drinking water induce only minor histological alterations in the seminiferous epithelium of the rat testis. A related substance, 2,4,5-trichlorophenoxyacetic acid is known to inhibit the uptake and metabolism of testosterone in the mouse prostate gland (Lloyd, Thomas \& Mawhinney, 1973), but Verschuuren et al. (1975) found only a slight, non-significant decrease in the weight of the rat prostate gland when MCPA was administered at a concentration of 3200 p.p.m. for a period of 90 days. At small doses the concentration of MCPA in the rat testes is low compared with that in plasma (Elo, 1976), but acute MCPA-Na poisoning causes an extensive increase in permeability of organs in the rat. In a chronic experiment 500 p.p.m. MCPA-Na in the drinking water increased permeability in the liver and at a concentration of 2500 p.p.m. permeability of the liver, brain and testis was affected (H. Elo \& P. Ylitalo, unpublished). The role of permeability changes in the development of the minor disturbances of spermatogenesis found in the present study, and whether these disturbances have any effect on the fertility of male rats, remains obscure.

We are grateful to Professor P. Tuohimaa for a critical review of the manuscript and thank $\mathrm{Mr}$ R. Fock (Bang \& Co. Ltd) for supplying MCPA. This work was supported by a grant from the Academy of Finland.

\section{References}

CourtneY, K.D. \& Moore, J.A. (1971) Teratology studies with 2,4,5-trichlorophenoxyacetic acid and 2,3,7,8-tetrachlorodibenzo-p-dioxin. Toxic. appl. Pharmac. 20, 396-403.

Elo, H. (1976) Distribution and elimination of 2methyl-4-chlorophenoxyacetic acid (MCPA) in male rats. Acta pharmac. toxic. 39, 58-64.

Leblond, C.P. \& CleRmont, Y. (1952) Definition of the stages of the cycle of the seminiferous epithelium in the rat. Ann. N.Y. Acad. Sci. 55, 548-573.

Lloyd, J.W., Thomas, J.A. \& MaWhinney, M.G. (1973) $2,4,5-\mathrm{T}$ and the metabolism of testosterone$1,2-{ }^{3} \mathrm{H}_{2}$ by mouse prostate glands. Archs envir. Hlth 26, 217-220.
SCHILleR, K. (1964) Beeinflussung der Fertilität von Ratten durch Stoffe mit Sonderwirkung im Kartoffelbau. 1. Mitteilung: Wuchsstoffe und Unkrautbekämpfungsmittel 2,4-D und MCPA. LandbForschVölkenrode 14, 111-114.

Verschuturen, H.G., Kroes, R. \& Den TonkelaAr, E.M. (1975) Short-term oral and dermal toxicity of MCPA and MCPP. Toxicology 3, 349-359.

YASUDA, M. \& MAEDA, H. (1972) Teratogenic effects of 4-chloro-2-methylphenoxyacetic acid ethylester (MCPEE) in rats. Toxic. appl. Pharmac. 23, 326-333.

ZYSK, J.R., BUSHWAY, A.A., WHISTLER, R.L. \& CARLTON W.W. (1975) Temporary sterility produced in male mice by 5-thio-D-glucose. J. Reprod. Fert. 45, 69-72. 